\title{
ROSJA JAKO TEKST W PROZIE WIKTORA PIELEWINA
}

\author{
RUSSIA AS TEXT IN VICTOR PELEVIN'S PROSE
}

\author{
TOMASZ NAKONECZNY
}

\begin{abstract}
The article presents the work of Victor Pelevin, one of the most famous contemporary Russian writers, in the context of changes in literary communication. The writer uses postmodern techniques and strategies (intertextuality, decanonization, heterogeneity) and traditional cultural motifs and themes (Russian and foreign) to compensate literature for the loss of its metaphysical attributes and authority of high art.
\end{abstract}

Tomasz Nakoneczny, Uniwersytet im. Adama Mickiewicza w Poznaniu, Poznań - Polska, tomnak@amu.edu.pl

W tytule niniejszych rozważań łatwo dopatrzyć się wskazówki interpretacyjnej, której w nim nie ma, a nawet - niejako z natury rzeczy - być nie może. Otóż zdaje się on sugerować, że będzie chodziło o kolejny przypadek wiązania i porządkowania zjawisk spowinowaconych wzajemnie na mocy pewnej koniecznej zależności: motywu, który dostarcza literaturze tworzywa i tekstu, który tworzywo to w określony sposób i z określoną intensywnością eksploatuje ${ }^{1}$. Czytelnik zaznajomiony z idiosynkrazjami literaturoznawstwa dostrzeże tu łatwo możliwość przeniesienia wymienionej pary pojęć na wyższy poziom ogólności, na którym uzyskałyby one bardziej instruktywne miana - treści i formy. I jakkolwiek co najmniej od czasu formalistów rosyjskich mniej czy bardziej świadomie wystrzegamy się przeciwstawiania ich sobie, a nawet roboczego choćby separowania, odwieczny nawyk, utrwalony $\mathrm{w}$ językowych schematach (zjawisko $X \mathrm{w}$ dziele $\mathrm{Y}$, twórczość Y na tle zjawiska x etc.), każe nam spodziewać się obiecujących rezultatów po takich i podobnych konfrontacjach. Wierzymy, że coś owocnego - poznawczo, estetycznie, moralnie $-\mathrm{z}$ nich wyniknie.

\footnotetext{
${ }^{1} \mathrm{~W}$ danym przypadku sprawę komplikuje dodatkowo okoliczność, że Rosja w roli tekstu może jawić się jako samoistnie problematyczna i wewnętrznie złożona formuła. O ile bowiem pytanie o zawartość rosyjskiej tekstualności odsyła do łatwo rozpoznawalnych narracji, mitów czy symboli, o tyle pytanie o jej mechanizmy generatywne otwiera pole dla wielostronnych spekulacji i uogólnień. Ponadto, co warto zauważyć, przyimek "jako" może sugerować postulat jakiejś Rosji „noumenalnej”, Rosji „poza-tekstem”. W moim ujęciu dystynkcje i rozróżnienia tego rodzaju podlegają unieważnieniu w kontekście twórczości Pielewina.
} 
Skoro więc "Rosję jako tekst” mielibyśmy rozumieć jako pewną autonomiczną strukturę symboliczno-znaczeniową, uobecniającą się w innej autonomicznej strukturze, jaką jest „proza Wiktora Pielewina”, moglibyśmy oczekiwać, że powstała w ten sposób całość pozwoli wpisać się w porządek interpretacyjny określony przez tradycyjne kategorie - wpływu, recepcji, transformacji, porównania (komparatystyki), naśladowania etc. etc. Że dowiemy się, jak Pielewin Rosję i jej odwieczne tematy rozgrywa, u których jej konceptualistów, dawnych i obecnych, się zapożycza, z którymi wchodzi w sojusze, których zwalcza, a od których się dystansuje. Sięgając zaś do kręgu zagadnień związanych bezpośrednio ze społeczną praxis, które nierzadko podlegają u Pielewina - w warunkach określonej poetyki - otwartej tematyzacji (szczególnie może w Omon Ra, Życie owadów, Generation ' $P$ ', Empire V, Batman Apollo), dowiemy się na przykład, kto lub co Rosją dzisiejszą naprawdę rządzi, jaki wpływ na jej mieszkańców mają procesy i wydarzenia o charakterze globalnym, już to $\mathrm{w}$ wymiarze pragmatyki polityczno-społecznej, już to $\mathrm{w}$ sensie foucaultowskim, głębszym i rozleglejszym zarazem.

Proponuję wyjście poza te schematy i spojrzenie na Pielewina-literata oraz Pielewina-myśliciela ${ }^{2}$ jako na zjawisko manifestujące nowy i odtąd prawdopodobnie normatywny (w miękkim znaczeniu) sposób komunikowania się literatury z jej odbiorcami.

Zmiana ta odbywa się na szerokim tle przeobrażeń intelektualnych, legitymizowanych i stymulowanych zarazem przez dwudziestowieczne przewroty metaliterackie (poststrukturalizm, kolejne "zwroty kulturowe" spod znaku cultural criticism), których rezultatem było odejście od traktowania literatury jako formy ekspresji o wysokim intelektualno-imaginacyjnym statusie, uprzywilejowanej na tle całego piśmiennictwa $\mathrm{z}$ racji unikalnej zdolności do łączenia metafizycznych aspiracji z formalną heterogenicznością̧3. Chroniczne wcześniej uwikłanie praktyk literackich $\mathrm{w}$ takie binarne

2 Określenie „myśliciel” rezonuje tutaj z jego znaczeniem utrwalonym w rosyjskiej tradycji. Oczywiście, stosując je do Pielewina, możemy mówić jedynie o pewnych ogólnych zbieżnościach na poziomie semiotycznym, nie zaś o prostej egzemplifikacji w stosunku do modelu. Zbieżności tych skłonny byłbym doszukiwać się w widocznym u Pielewina zamiłowaniu do polisemii pojęć-kluczy, w odwoływaniu się do etymologicznych i głęboko symbolicznych właściwości nazw i imion (Empire $V$, Batman Apollo, Generation ' $P$ '), w zacieraniu różnic między literaturą a filozofią (Czapajew i Pustka), a także w stylu jego autokreacji jako osoby publicznej (aura tajemniczości, niejednoznaczności, skłonność do rezonerstwa obejmującego bardzo szeroki zakres tematów). Por. J. F a r y n o, Мыслитель / Мысль, [w:] Mentalność rosyjska, red. A. de Lazari, Katowice 1995, s. 55-56.

${ }^{3}$ Oczywiście, zanik metafizycznego rdzenia i wynikająca stąd relatywizacja znaczeń, norm i hierarchii jest zjawiskiem we współczesnych kulturach euroatlantyckich powszechnym, i literatura, ani jako forma dyskursu, ani jako sztuka słowa, nie stanowi tutaj wyjątku. Chodzi zatem właśnie o tę unikalną koniunkcję własności metafizycznych 
opozycje jak fikcja i rzeczywistość ${ }^{4}$, sztuka i rzemiosło, autentyzm i formalizm, społeczne zaangażowanie i artystowskie pięknoduchostwo etc. ${ }^{\circ}$, związane było silnie z potrzebą poszukiwania w literaturze tego, co „twórcze", „uniwersalne” bądź „wartościowe”, i odróżniania go od jakości przeciwstawnych. Utrzymująca się dzięki temu, nie zawsze zresztą respektowana świadomie, hierarchia tematów, tekstów i autorów pozwalała korygować rozmaite zakłócenia komunikacyjne na płaszczyźnie nadawczo-odbiorczej, jak choćby te natury temporalnej, gdy publiczność nie nadążała za nowinkami estetycznymi. Normalizacja pozostawała niezmiennie w zasięgu ręki, właśnie dzięki możności odwołania się do autorytetu hierarchii. Jeśli upa-

i formalnej swobody, które przez wieki odróżniały literaturę od innych form dyskursu, na przykład filozoficznego. Im słabsze literatura znajdowała wsparcie ze strony „świata wartości", tym większa była potrzeba definiowania jej swoistości w kategoriach retorycznej maszynerii, siły perswazji i metaforycznego skomplikowania. A wszystko to na tle powszechnego „odmetafizyczniania” dyskursów. Detronizacja literatury odbywała się w efekcie pod wpływem zamazywania granicy między tekstami literackimi i nieliterackimi. Trudno przecenić udział, jaki miały w tym procesie rozmaite dyskursy mniejszościowe (np. gender, postcolonial studies) czy historycystyczne (New Historicism).

${ }^{4}$ Za najważniejszą - $\mathrm{w}$ perspektywie niniejszych rozważań - z takich par uważam fikcję i rzeczywistość. Ich wzajemne przemieszczenia semantyczne i wzajemną dyfuzyjność (ucieleśnione żywo w Baudrillardowskiej wersji zjawiska) wypada uznać za istotny definiens kultury ponowoczesnej. Zjawiska te wydają się źródłem atrakcyjności postmodernizmu jako domeny nieograniczonej kreacyjności, a zarazem klęską elitarnego modelu literatury (sztuki) i quasi-kapłańskiego (etosowego) modelu pisarstwa. Inspirujące $\mathrm{w}$ tym kontekście uwagi na temat fikcjonalizacji rzeczywistości i antyfikcjonalności sztuki współczesnej wypowiada O. Marquard. Zob. O. M a r q u a r d, Aesthetica $i$ anaesthetica. Rozważania filozoficzne, tłum. K. Krzemieniowa, Warszawa 2007. O funkcjonalizacji sztuki skutkującej deregulacją binarnej opozycji „fikcja-rzeczywistość” pisze z kolei Zygmunt Bauman. W eseju Ponowoczesność, czyli o niemożliwości awangardy zauważa on, że

sztuka jest jedną z wielu alternatywnych rzeczywistości, z których każda posiada własny zestaw milcząco przyjętych założeń i własne procedury i mechanizmy ich ",uprawdziwiania" oraz samoodtwarzania się. Pytania o to, która z rzeczywistości jest „bardziej rzeczywista", która pierwotna, a która wtórna, która dla której służyć ma za punkt odniesienia i sprawdzian poprawności, tracą sens; a jeśli nawet zadaje się je z nawyku, to nie wiadomo przecież, jak zabrać się do szukania odpowiedzi [...].

Z. B a u m a n, Ponowoczesność jako źródło cierpień, Warszawa 2000, s. 163.

${ }^{5} \mathrm{~W}$ sytuacji generalnej niechęci do binarnego wartościowania tekstu literackiego twórczość Pielewina może służyć za nader wyrazisty przykład fundamentalnych trudności klasyfikacyjnych. Bo gdzie na przykład na wciąż respektowanej przez wielu krytyków skali wartości, rozciągającej się między biegunami rozrywki i kultury wysokiej, umieścić Pielewina, pisarza cenionego przez literaturoznawców, a jednocześnie czytanego chętnie przez odbiorcę masowego? Kultury wysokiej - co frapujące na tle powszechnej deregulacji hierarchii estetycznych - wciąż jeszcze opisywanej w terminach artyzmu, elitarności, powołania, zaangażowania czy krytycyzmu. 
dała dotychczasowa, $\mathrm{w}$ tle zawsze kształtowała się natychmiast jakaś zastępcza. Można powiedzieć, że sama zasada hierarchiczności, razem z wspierającym ją ideologiczno-metafizycznym zapleczem, stanowiła niezawodny, stabilizujący układ odniesienia, i to również - jako się rzekło - w sytuacjach radykalnych przewartościowań kulturowych (vide imaginarium romantyczne w miejsce ratio czy utopia modernistyczna w miejsce tradycji).

Kultura, w tym literatura, pomoderna, jak się wydaje, niewiele sobie robi z podobnych dystynkcji. W swoich zaś postmodernistycznych odmianach programowo na ogół odmawia uznania wiarygodności jakichkolwiek kryteriów (relewantnych, obiektywnych, uniwersalnych), które uzasadniałyby potrzebę odróżniania esencjalnego od ludycznego, artystycznego od komercyjnego, czy też tego, co ważne dla profesjonalnego literaturoznawcy, od tego, co zajmujące dla tak zwanego zwykłego odbiorcy.

Uważam, że zasygnalizowana wcześniej zmiana sposobu komunikowania się autora $\mathrm{z}$ odbiorcami może być identyfikowana nie tylko jako istotny aspekt "rewolucji” postmodernistycznej, ale również - a może przede wszystkim - jako oznaka niejednoznaczności jej rezultatów (czytaj - jej wewnętrznej sprzeczności), a zarazem podległości zasadzie kompensacyjnej, znanej dobrze (choć nie zawsze artykułowanej) z poprzednich rewolucji estetycznych: utrata danej właściwości kompensowana jest pojawieniem się innej, najczęściej tamtą utraconą markującej6. Wydaje się na przykład, że utrata metafizycznego zaplecza jest przez literaturę postmodernistyczną kompensowana przez szereg funkcjonalności, niegdyś utożsamianych głównie $\mathrm{z}$ formalną organizacją dzieła, a dziś stanowiących o jego wartości tout court, takich jak bogata intertekstualność, złożone, wielopoziomowe strategie narracyjne i fabularne symulujące istnienie tajemnicy (głębi, właściwego przesłania, ostatecznego sensu etc.), czy wreszcie bezpośrednia tematyzacja rozmaitych wątków filozoficznych etc. Trudno przy tym o twórczość literacką, która by te przeobrażenia odzwierciedlała w sposób bardziej sugestywny, przynajmniej na gruncie rosyjskim, aniżeli twórczość Wiktora Pielewina 7 .

\footnotetext{
${ }^{6}$ Idea kompensacji jako zasady kulturotwórczej znalazła sobie w nowoczesnej myśli europejskiej osobne miejsce; dość przywołać tu pożytkujące ją refleksje Freuda, Sartre'a czy Marquarda. U tego ostatniego, na którego przyjdzie mi się jeszcze powołać, świecka, odmetafizyczniona kultura nowożytna rezonuje stale z oficjalnie przezwyciężoną na jej gruncie ideą teodycei (dla Marquarda odniesieniem jest jej Leibnizjańska wersja). Przejawem tej łączności jest właśnie zasada kompensacji, uobecniająca się na przykład w zjawisku bonizacji zła. Wykorzystanie tej zasady do interpretacji myśli i praktyk postmodernizmu wydaje się otwierać bardzo interesującą perspektywę badawczą.

${ }^{7} \mathrm{~W}$ tym szerszym niż historycznoliteracki kontekście, w jakim osadziłem swoje rozważania nad przypadkiem Pielewina, staram się konsekwentnie wystrzegać odniesień do nader rozległego obszaru dyskusji i sporów, jakie toczą się od lat 90 . ubiegłego
} 
Nie ulega wątpliwości, że wielkie powieści Dostojewskiego czy Bułhakowa można traktować - niezależnie od znacznej niekiedy nadwyżki czynnika estetycznego - jako poważne diagnozy kondycji ludzkiej. Innymi słowy, przypisywana im uniwersalność i kulturotwórcze znaczenie wynikają w znacznej mierze stąd, że uważa się, iż mówią one coś istotnego o człowieku jako takim i o człowieku swojego czasu. Ich wymiar fikcjonalny współistnieje przekonująco dla naszej wyobraźni i wiarygodnie dla naszego intelektu, z rudymentami porządku określanego jako rzeczywistość pozaliteracka, z którym to porządkiem kojarzymy zwykle takie kategorie jak natura ludzka, społeczeństwo czy epoka.

Tymczasem na gruncie kultury pomodernej (literatura postmodernistyczna stanowi jej najważniejszą dla niniejszych rozważań ekspozyturę) relacja fikcjonalności i rzeczywistości stała się wieloznaczna (zob. przyp. nr 4). Przeniknięcie tej wieloznaczności do rosyjskiej kultury nieoficjalnej (konceptualizm, metarealizm, postmodernizm etc.) w latach 70. i 80. minionego stulecia okazało się zaczynem niezwykle twórczego fermentu. Zastanawiać przy tym może tak skala, jak intensywność zjawiska. W dodatku międzynarodowy sukces pisarzy rosyjskich kojarzonych z nową literaturą (Wieniedikt Jerofiejew, Wiktor Jerofiejew, Pielewin, Sorokin, Tatiana Tołstoj) wykracza, jak się wydaje, poza tradycyjne, i tak przecież duże, zainteresowanie literaturą rosyjską jako taką. Czy bardziej należy tłumaczyć to „imperialną" nośnością kultury wielkiego kraju czy też oryginalnością i kreatywnością samych autorów (bo że generalnie jednym i drugim pospołu, to pewne), pozostaje pytaniem z natury nierozstrzygalnym, choć frapującym. Istnieją

stulecia na temat „postmodernistyczności” tego pisarza. O rozpiętości skali ocen niech zaświadczą opinie Siergieja Korniewa i Dmitrija Szamańskiego.

Przyjrzawszy się uważniej - pisze Korniew - nagle ze zdziwieniem odkryłem, że z Pielewina tak naprawdę - ideowo, w treści - żaden postmodernista, a najprawdziwszy rosyjski pisarz klasyczny-ideolog, w rodzaju Tołstoja czy Czernyszewskiego.

Co więcej, Pielewin nie jest

po prostu ideologiem, lecz natrętnym, beznadziejnym ideologiem, który dosłownie każdą swoją linijką uporczywie i otwarcie wtłacza do głowy czytelnika jedną i tę samą moralnometafizyczną teorię.

С. К о р н е в, Столкновение пустот: может ли постмодернизм быть русским и классическим?, „Новое литературное обозрение” 1997, № 28. Tłum. własne - T. N. Z kolei Szamanski widzi w Pielewinie postmodernistę par excellence, modelowe ucieleśnienie jego charakterystycznych idiosynkrazji, w dodatku objawione we właściwym czasie i miejscu.

Wiktor Pielewin - pisze krytyk - pojawił się w porę. [...] Pustka wśród literatur, pustka w znaczeniu metafizycznym: postmodernistyczne absolutne zero. Wiktor Pielewin, wydany przez tę epokę, proklamował ją, umieścił na ostrzu swojego talentu i stał się nią. Powiedzieć, że Pielewin jest postmodernistą idealnym, to za mało. On jest żywym postmodernistycznym wszystkim i niczym. Ucieleśnieniem i symbolem pustki.

Д. Ш а м а н с к и й, Пустота (Снова о Викторе Пелевине), „Мир русского слова” 2001, № 3 . 
natomiast badacze, jak Michaił Epsztejn, którzy fenomen rosyjskiego postmodernizmu skłonni są tłumaczyć ogólną podatnością nowożytnej kultury rosyjskiej na symulakrowość (przewaga „znaczącego" nad "znaczonym” posunięta niekiedy aż do nieuwzględniania tego drugiego; zdolność znaków do wyodrębniania się i funkcjonowania niezależnego od rzeczywistości pozajęzykowej, uwidoczniona zwłaszcza w lokalnych projektach modernizacyjnych, takich jak reformy Piotrowe czy sowiecki komunizm etc.) ${ }^{8}$.

Przyjmując taką perspektywę i nakładając na nią przywołany wcześniej proces dezintegracji klasycznego modelu pisarstwa i literackości, łatwiej zrozumieć gwałtowną inwazję do literatury intertekstu. Odgrywa on dwie pozornie sprzeczne role komunikacyjne: środka upraszczającego porozumienie z odbiorcą (gdy posługując się kliszami języka kultury popularnej, przywołuje echa dawnej wspólnoty "kanonicznej”) i utrudniającego to porozumienie (gdy montując własne systemy znakowe, o nierzadko znacznym stopniu wyrafinowania, ujawnia właściwości kompensacyjne $\mathrm{w}$ stosunku do utraconej logocentryczności - metafizycznej, poznawczej etc.). Pozorna sprzeczność bierze się stąd, że obie te role są w istocie wzajem komplementarne, jako że żadna nie wydaje się dla postmodernizmu do przyjęcia bez drugiej: poprzestając na pierwszej, stałby się formą rozrywki, na drugiej zaś - sprzeniewierzyłby się swoim wolnościowym aspiracjom i sceptycznemu usposobieniu. Dlatego nie sposób nie zauważyć, że literatura postmodernistyczna wykorzystuje, i to niezwykle niekiedy efektywnie (casus Pielewina), swój intertekstualny potencjał do przechwytywania i kopiowania wzorów kultury popularnej, do rozmywania w tych wzorach idei i obrazów traktowanych niegdyś ze śmiertelną powagą, a nawet - na gruncie kultury rosyjskiej - swoiście sakralizowanych (naród, sprawiedliwość, prawda). A wszystko to przy jednoczesnym zachowywaniu atrakcyjności dyskursu żerującego na pewnych ambicjach intelektualnych odbiorcy masowego9.

8 Zob. Светлой памяти постмодерна посъящается.., [w:] źródło elektroniczne: http://xz.gif.ru/numbers/64/epshtein- savchuk/(16.09.2015).

${ }^{9} \mathrm{Te}$ ambicje należałoby rozumieć nie w kategoriach poznania (gnoseologicznych), lecz uznania (psychologicznych i socjologicznych). Skoro bowiem postmodernizm nie rości sobie pretensji do prawdy, koherencji, systemowości, warto zastanowić się - w duchu przywołanej wcześniej zasady kompensacyjnej - czym ewentualnie (i czy w ogóle) te staromodne wartości i cele zostały zastąpione. Skłonny jestem uważać, że odpowiedzi należałoby poszukiwać w kręgu takich pojęć jak uznanie i prestiż. A sprowadzając rzecz do węższego wymiaru - w kręgu rynkowych miar wartości. Ciekawym odniesieniem dla takiego rozumowania mogłoby być to, co Bauman pisze o losach dwudziestowiecznej sztuki awangardowej. Jej klęska polega zdaniem myśliciela na tym, że z ekscentrycznej kapłanki modernistycznej utopii przeobraziła się ona w specyficzny ersatz statusu społecznego. Powiada Bauman:

Moc stratyfikacyjną, jaka niegdyś doprowadziła do triumfu / klęski awangardy, posiada dziś nie tyle dzieło sztuki, co miejsce, w jakim się je nabyło, i cena, jaką się za nie zapłaciło. 
Jak się to ma do tytułowego zagadnienia Pielewinowskich aktualizacji rosyjskiego tekstu? Po tym, co zostało powiedziane, łatwiej zapewne sobie wyobrazić, że oczekiwanie, iż będziemy tu mieli do czynienia z prostym odzwierciedlaniem się jednego porządku symbolicznego $\mathrm{w}$ drugim, musi jawić się jako nadmiernie prostoduszne. I że nie chodzi wyłącznie o to, że absorpcja Rosji jako residuum tekstualnego, narracyjnego czy mitologicznego dokonuje się u Pielewina $\mathrm{w}$ trybie dekonstrukcyjnym ${ }^{10}$. Sama dekonstrukcja nie przesądza zresztą kwestii stosunku do rzeczywistości; nie $\mathrm{w}$ takim sensie przynajmniej, by tę ostatnią dało się zupełnie konsekwentnie wyłączyć spod zasięgu „,konstruktywnych" aspiracji samych pisarzy. Istnieją przecież badacze, jak Olga Bogdanowa, którym przynależność Pielewina do postmodernizmu jawi się jako połowiczna, właśnie dekonstrukcyjno-formalna, przy zachowaniu przezeń respektu dla nieredukowalnych obszarów bytu. „Jeśli postmoderniści - pisze Bogdanowa - przede wszystkim zadowalają się uświadamianiem "nihilizmu” i dekonstrukcji świata zewnętrznego, to Pielewin tworzy własny świat. Jeśli postmoderniści, mówiąc o zniszczeniu świata zewnętrznego, mają jednocześnie na myśli pełną likwidację świata wewnętrznego, to Pielewin nie przyjmuje możliwości odmówienia człowiekowi jakichś pozytywnych cech, wewnętrznej psychologicznej rozumności podmiotu (czy to człowieka, czy zwierzęcia, owada, rośliny, promienia słonecznego czy cząsteczki pyłku)"11. Irina Skoropanowa z kolei zwraca uwagę na poznawczą orientację twórczości Pielewina, co samo w sobie kazałoby jej postmodernistyczny kreacjonizm traktować z pewną ostrożnością, jako część bardziej złożonej całości estetyczno-światopolądowej.

Pod tym względem nie różnią się dzieła sztuki od innych symboli pozycyjnych pozyskiwanych za pośrednictwem rynku.

Z. B a u m a n, op. cit., s. 162. Rozszerzając Baumanowską wykładnię o motywację kompensacyjną, można by uznać, że nowoczesne (ponowoczesne?) czytanie literatury służy - obok zaspokajania określonych potrzeb osobistych - manifestowaniu własnej elitarności, przynależności - choćby i symbolicznej tylko - do pewnej wspólnoty intelektualnej. Pisanie natomiast jawiłoby się w tym kontekście nie tyle jako realizacja wewnętrznego imperatywu twórczego czy źródło zarobku (choć te motywacje nie ulegają tutaj unieważnieniu), co zwłaszcza jako manifestacja biegłości w posługiwaniu się ezoterycznymi kodami kultury, dostępnymi nielicznym, wymagająca posiadania unikalnych kompetencji.

${ }^{10}$ Nie chodzi też, co warto przy okazji zaznaczyć, o możliwość interpretowania tekstów autora Generation ' $P$ ' w kategoriach ironii czy parodii, do czego Bachtinowska progenitura badawcza, tak w Rosji, jak na świecie, wykazuje przemożną skłonność. Ironia i parodia, podobnie jak dekonstrukcja, zakładają przecież istnienie jakiegoś pozytywnego dla swoich obiektów odniesienia.

11 О. Б о г д а н о в а, Постмодернизм В контексте современной русской литературы (60 - 90-е годы ХХ века - начало ХХІ века), Санкт-Петербург 2004, s. 301. Tłum. własne $-\mathrm{T}$. N. 
Wiktora Pielewina - pisze badaczka - interesują przede wszystkim procesy zachodzące $\mathrm{w}$ sferze poznania, w zbiorowej nieświadomości i indywidualnej psychice, ich wpływ na bieg historii, społeczne zachowanie ludzi. Stąd zainteresowanie fenomenem ideologii, reklamy, możliwościami technologii informatycznych, psychodelią, stąd badanie stanu współczesnego rosyjskiego archetypu narodowego ${ }^{12}$.

Znaczenie i wartość formalnych uwikłań prozy Pielewina - w literackość, w intertekstualność, w postmodernistyczny persyflaż - bywa $\mathrm{w}$ takiej perspektywie interpretacyjnej pomniejszane na rzecz uwypuklania jej egzystencjalnej bądź epistemologicznej doniosłości. W wersjach natomiast radykalnie "pro"- i „anty-postmodernistycznych", jak w przypadku Korniewa i Szamanskiego ${ }^{13}$, mamy do czynienia z próbą jednoznacznego przezwyciężenia aporii interpretacyjnej, jaka powstaje wskutek uwikłania Pielewina w opozycję mimetycznej natury: naturalista-konstruktywista (inaczej: tradycjonalista-postmodernista). Kto wie, czy odpychanie się, a nawet wykluczanie wzajemne, tych odczytań nie sprawia, że łatwiej w ostatecznym rozrachunku widzieć $w$ Pielewinie ukrytego pod maską szydercy i internacjonała rosyjskiego - toutes proportions gardées - klasyka, tradycyjnego myśliciela i moralistę. Szłoby to $\mathrm{w}$ pewnej mierze w sukurs mojej propozycji, by casus Pielewina rozpatrywać w kategoriach kompensacji i symulacji.

O co więc chodzi, można zapytać, gdy mowa o rosyjskim tekście w porządku Pielewinowskich wariancji? Otóż niezależnie od tego, ile w Pielewinie „formalnego" postmodernisty, a ile "treściwego" tradycjonalisty, pochodzące ze wspomnianego residuum tekstualnego motywy nie funkcjonują u tego autora jako wehikuły znaczeń i sensów, dla których sankcją pozostawałaby wspólnota interpretacyjna z jej idiosynkratyczną epistemologią, z jej wyrazistymi preferencjami i ustabilizowanymi hierarchiami. Zatraciły przy tym nie tylko swoją powagę, ale i zdolność do koherentnego współistnienia, a co za tym idzie - do konstytuowania światów, w których czytelnik mógłby rozpoznawać swój własny świat. Do tego stopnia, że nawet sugestywny początkowo $\mathrm{w}$ swoim realizmie obraz narodzin rosyjskiego kapitalizmu czasów Jelcyna, z jakim mamy do czynienia w Generation ' $P$ ', rozpada się $\mathrm{w}$ finalnej scenie powieści na niemożliwe do złożenia kawałki. Dzieje się tak, gdy zostaje ujawnione, że władzę w Rosji sprawuje nie - jak można by się spodziewać wcześniej - rynek, nie postkomunistyczna nomenklatura, nawet nie wszechobecne media, lecz ...międzynarodówka "Chaldejczyków", swoiste deus ex machina, którego chyba nie sposób brać serio nawet $\mathrm{w}$ symbolicznej funkcji. Można, oczywiście, bardzo różnie tłumaczyć moment konfuzji, jakiej doświadcza niechybnie w podobnych ra-

12 И. С к о р о п а н о в а, Русская постмодернистская литература, Москва 2001, s. 433. Tłum. własne $-\mathrm{T}$. N.

${ }^{13}$ Zob. przypis nr 7. 
zach czytelnik poszukujący u Pielewina, osławionego swoim image'em niepokornego demaskatora, ukrytej a przenikliwej diagnozy rosyjskiego życia. Można na przykład ograniczać rozmiar konfuzji przez związanie jej wyłącznie z osobliwościami Pielewinowskich fabuł, według Wiaczesława Kuricyna prostych "do granic prymitywności"14, obliczonych na prowokacje i popularność u widza masowego, wartość diagnostyczną Pielewina-obserwatora szacując na podstawie opisowych bądź quasi-dyskursywnych partii jego prozy, a także - w niemniejszej mierze - na podstawie jego wypowiedzi programowych w wywiadach (niezbyt wprawdzie licznych, lecz wyrazistych i intelektualnie spójnych).

Weźmy tu jako przykład filozoficzne dialogi Pietki i Czapajewa z Matego palca Buddy, które - niezależnie od swoich funkcji fabularnych i charakteryzujących - pozwalają się wyodrębnić jako zwarty i logiczny wywód na temat świadomości. Wywód frapujący intelektualnie nie tylko za sprawą swojej logiczności, ale i mocnego osadzenia w spekulatywnej i duchowej tradycji Wschodu oraz Zachodu. Czy też weźmy charakterystykę oranusa w Generation ' $P$ ', która przy całej swojej parodyjnej prześmiewczości zawiera przecież elementy konstruktywnej dezawuacji współczesnej kultury, rezonujące niekiedy $\mathrm{z}$ najbardziej wpływowymi diagnozami Baumana czy Giddensa. Z kolei powieści takie jak Życie owadów, Generation ' $P$ ' czy Omon $R a$ potrafiłyby ukontentować badacza tropów postkolonialnych: prowincjonalność bohaterów rosyjskich, z właściwymi jej tęsknotami i kompleksami wobec Zachodu, została przez Pielewina oddana - mimo satyrycznej deformacji $-\mathrm{z}$ dużą psychologiczną sugestywnością ${ }^{15}$. Listę przykładów

${ }^{14}$ Kuricyn ogromną popularność Pielewina wiąże z jego generalnym ukierunkowaniem na kulturę masową i rzeczywistość wirtualną. Przejawem tego jest - w wymiarze struktury dzieła - nie tylko prostota fabularna, ale również bogata intertekstualność, skłonność do prowokacji oraz fotograficzna wierność realiom sowieckiego i posowieckiego świata. В. К у р и ц ы н, Русский литературный постмодернизм, Москва 2000, s. 174-175.

15 Jako przykłady dość przywołać tu kulturowe fascynacje żeńskich bohaterek Życia owadów, Mariny i Nataszy (matki i córki). Gdy pierwsza próbuje kształtować własne życie (groteskowo nieudane) na wzór francuskich filmów o miłości, druga rozpaczliwie próbuje dostosować się we wszystkim do oczekiwań Amerykanina Sama, swojego ukochanego. W Omon $R a$ z kolei wyzyskuje Pielewin motyw rywalizacji zimnowojennej. Symbolem tęsknot do lepszego świata i zarazem czynnikiem obnażającym gorszość świata własnego jest tutaj radziecka kosmonautyka, z jej spektakularnymi osiągnięciami i z jej - niezrównanie w powieści wykpioną - fasadowością, skrywającą mechanizmy propagandowej manipulacji i materialne ubóstwo społeczeństwa.

Nory, w których upływało nasze życie - wspomina główny bohater powieści - rzeczywiście były ciemne i brudne, my sami byliśmy pewnie warci tych nor - ale w granatowym niebie nad naszymi głowami wśród rzadkich i bladych gwiazd istniały szczególne świetliste punkty, sztuczne, wolno pełznące pośród gwiazdozbiorów, stworzone tu, na ra- 
poświadczających silne i trzeźwe związki prozy Pielewina z uniwersum kulturowym oraz z mentalnością współczesnych Rosjan można by, rzecz jasna, wydłużyć.

Czy oznacza to jednak, że niezależność autora Czapajewa i Pustki od normy wspólnotowej - w sensie, jaki wysłowiony został powyżej - jest tylko pozorna? Że pod maską postmodernistycznego gracza mruga do nas porozumiewawczo satyryk lub - jeśli ktoś woli - krytyk społeczny, odwołujący się do wspólnego z czytelnikiem systemu wartości, wyczulonego na te same co on absurdy i deformacje życia? Myśliciel włączający się twórczo w żywy nurt wielowiekowej refleksji nad naturą jaźni? Taka interpretacja szłaby w stronę ujęcia etnocentrycznego lub w dowolny inny sposób ograniczającego zasięg Pielewinowskiej kreatywności. Tymczasem ta ostatnia siłę kompensacyjną $\mathrm{w}$ stosunku do utraconej przez literaturę autorytatywności i metafizyczności czerpie właśnie ze swojej intertekstualnej nieograniczoności i autorskiej nieuchwytności. Z drugiej strony, jak już wiemy, z rozpoznawalności, jaką zapewnia jej umiejętność aktualizowania w popkulturowej semiotyce starych, rosyjskich na ogół, wzorów. Na tym właśnie, jak się wydaje, polega niemożność ostatecznego i rozstrzygającego przyłapania Pielewina na byciu "rosyjskim klasykiem” bądź „postmodernistycznym internacjonałem" - jest on zbyt "uniwersalny" dla pierwszej z perspektyw, a zbyt "lokalny" dla drugiej.

Za tym, że Pielewin jednak przekracza / znosi granice oddzielające obszar gry literackiej od „realnej” eksploracji rzeczywistości, przemawiają co najmniej dwie okoliczności. Po pierwsze to, że krytycyzm pisarza, o jakim była mowa, a w jakim można by upatrywać przejawów jego zakorzenienia we wspólnotowych strukturach wartości, nie wydaje się wymierzony $\mathrm{w}$ jakiś określony porządek społeczny czy aksjologiczny. Jawi się - co już zostało podkreślone - jako ze wszech miar „uniwersalny"16. Podkreśla to okoliczność, że Pielewinowi właściwa jest, co sam zresztą przyznaje w jednym z wywiadów, orientacja epistemologiczna, nie zaś ontologiczna;

dzieckiej ziemi, wśród rzygowin, pustych butelek i papierosowego dymu - zbudowane ze stali, półprzewodników i elektroniki i teraz lecące w kosmosie.

W. P i e 1 e w i n, Omon Ra i inne opowieści, tłum. E. Rojewska-Olejarczuk, Warszawa 2007, s. 29. Natomiast w Generation ' $P$ ' Wowczyk Mały formułuje rosyjski kompleks $\mathrm{z}$ właściwą sobie dosadną przenikliwością:

Brakuje nam narodowej toż-sa-moś-ci [...]. Czeczeni ją mają, a my nie. Dlatego inni traktują nas jak gówno. Tak że potrzebna jest wyraźna i jasna rosyjska idea, żeby człowiek mógł każdemu skurwielowi z jakiegoś Harvardu zwyczajnie powiedzieć: sraty-taty, dupa w kraty, tak na nas patrzeć nie wolno. Zresztą sami też powinniśmy wiedzieć, skąd nasz ród.

W. P i e l e w i n, Generation 'P', tłum. E. Rojewska-Olejarczuk, Warszawa 2006, s. 183.

${ }^{16}$ Podkreślona cudzysłowem umowność narzuca się tu z nieodpartą koniecznością, jako że termin w jednym z podstawowych użyć posiada konotację logocentryczną, mylącą w kontekście tutaj rozpatrywanym. 
sprawia to, że jego światy przedstawione osadzone są często $\mathrm{w}$ płynnych i z natury niedookreślonych przestrzeniach jaźni, nie zaś w stabilnych strukturach mitu czy wielkich narracji przeszłości. Po drugie, mimo pozorów, jakie może stwarzać jego obrazowa intertekstualność, Pielewin nie funkcjonuje $\mathrm{w}$ ramach tradycyjnego modelu literaturocentrycznego i rosjocentrycznego, tak charakterystycznego dla rosyjskiej percepcji rzeczywistości i dla etosu rosyjskiej inteligencji. Rosja nie jest dla niego podstawowym, a już na pewno nie jedynym układem odniesienia.

Miarą stopnia odejścia pisarza od standardowych w kulturze rodzimej ukształtowań obrazu Rosji i rosyjskości może być fakt, że nie wyodrębniają się one $u$ tego pisarza jako samodzielna, niezależna struktura symbolicznoznaczeniowa (zupełnie inaczej niż ma to miejsce $\mathrm{w}$ ramach głęboko zinternalizowanej przez Rosjan i powielanej w dyskursach zachodnich opozycji Rosja - Zachód). Warto bowiem zwrócić uwagę na zachodzącą w prozie Pielewina izomorficzność pojęć rosyjskie-sowieckie-postsowieckie-globalne, modelowo widoczną w Generation ' $P$ '.

Pisarz kwestię rosyjskości podejmuje bezpośrednio, $\mathrm{w}$ jednym $\mathrm{z}$ wywiadów.

Co to właściwie znaczy - zastanawia się - że książka jest rosyjska? Czy oznacza to wyssane $\mathrm{z}$ mlekiem matki prawosławie lub wiarę w mesjańską rolę Rosji czy też jakąkolwiek poważnie potraktowaną ideologię, drogę, którą często zdarzało się iść w ciągu ostatnich dwóch stuleci? W tym sensie nie myślę, bym podpadał pod takie określenie, ponieważ nigdy nie byłem natchniony niczym podobnego rodzaju. Czy oznacza to podążanie za rosyjską tradycją literacką? Jedyna prawdziwa rosyjska tradycja literacka to pisanie książek w taki sposób, w jaki nie robił tego wcześniej nikt. Żeby stać się częścią tradycji, powinno się jej wyrzec - to warunek konieczny, choć niewystarczający. Jeśli mówi pan o wyobrażeniu unikalnego życiowego doświadczenia rosyjskiego, to jest to tylko inna kombinacja tych samych składników, z których składa się unikalne doświadczenie życiowe francuskie czy niemieckie, tylko zestawionych $w$ innych proporcjach. Te składniki to cierpienie i radość, nadzieja i rozpacz, współczucie i wyniosłość, słowa miłości, krzyki nienawiści. Każdy z nas zna wszystkie te składniki, dlatego pan może czytać Antona Czechowa, a ja mogę czytać Kinky Friedmana. [...] Nie ma niczego rosyjskiego (русского), co byłoby wyjątkowo rosyjskim (русским). Со więcej nie ma absolutnie niczego takiego jak rosyjskie tematy. Tak jak nie ma żadnych innych narodowych tematów. Jeśli spróbuje pan pisać długo i konsekwentnie o Rosji, nie uda się to panu: nawet jeśli pierwsze zdanie będzie o Rosji, drugie i trzecie będą już o czymś innym. I gdy ostatecznie zakończy pan książkę, okaże się, że napisał ją pan o sobie samym ${ }^{17}$.

Jak powiada jedna z postaci w Czapajewie i Pustce: "Za każdym razem, gdy pojawi się w świadomości pojęcie i obraz Rosji, trzeba pozwolić im

17 Л. К р о п ы в ь я н с к и й, Интервью с Виктором Пелевиным, [w:] źródło elektroniczne: http://pelevin.nov.ru/interview/o-bomb/1.html (15.08.2015). 
roztopić się we własnej naturze. A że pojęcie i obraz Rosji żadnej własnej natury nie mają, w rezultacie Rosja okaże się świetnie ustawiona"18. Stwierdzenie to powinno zostać potraktowane $\mathrm{z}$ należną powagą: przywołana w nim implicytnie tytułowa Pustka okazuje się bowiem w świecie Pielewina brakującym ogniwem między rzeczywistością a literaturą, między Rosją-tekstem a jej aktualizacją w twórczości pisarza. Jeśli pojęcie i obraz Rosji nie mają własnej natury, wspólnota przestaje być - niejako mimowolnie - konieczną depozytariuszką ich znaczeń. Staje się nią wyobraźnia. Unieważnia to (a w pewnym sensie odwraca) klasyczny, wyrażony w tytule niniejszych rozważań, wektor zależności: to nie obraz Rosji w określonej twórczości, lecz określona twórczość w obrazie Rosji staje się zagadnieniem prawdziwie godnym uwagi.

Wyłączenie autorskiej wizji świata spod jurysdykcji tradycyjnej wspólnoty interpretacyjnej odbiera wprawdzie tekstowi potocznie rozumianą wiarygodność i autorytet, ale jednocześnie między autorem, czytelnikiem i tekstem uruchamia nowe, wielorakie interakcje. Weźmy pod uwagę, w kontekście Pielewina, tylko dwa możliwe następstwa takiej sytuacji. Po stronie odbiorcy - pragnienie przezwyciężenia interpretacyjnego relatywizmu i ulokowania swoich oczekiwań w sferach mniej podatnych na deliberację i wieloznaczność: estetycznej sensu stricto, pojmowanej w kategoriach czystej rozrywki, gdzie podstawowymi wyznacznikami „ładu” pozostają bieguny akceptacji i odrzucenia, oraz moralnej sensu largo, pojmowanej jako humanistyczna perspektywa otwartości na formacyjną rolę wyobraźni. Po stronie autora natomiast - nasiloną potrzebę autokreacji oraz eksponowania własnego nonkonformizmu i oryginalności, bądź - z drugiej strony - pokusę rezonerstwa, asocjującą z literaturocentryczną i etosową charakterystyką pisarstwa dawniejszego typu; rezonerstwa, dla którego istotnym odniesieniem pozostają tradycyjne narracje i mity.

Obie te figury, nonkonformisty i rezonera, pozwalają się rozpoznać w postawie Pielewina-autora i Pielewina-postaci publicznej. W tym drugim przypadku wyraziściej co do samej formy przekazu (wywiady i spotkania autorskie), choć zarazem $\mathrm{w}$ atmosferze ogólnej, najpewniej kreowanej z rozmysłem, nieuchwytności i tajemniczości. Dostrzegam w tym kolejny przejaw logiki kompensacyjnej: jest to symulacja quasi-kapłańskiego $\mathrm{w}$ rosyjskiej tradycji statusu pisarza oraz, w mniejszym stopniu, równie ważnej dla tej tradycji figury myśliciela (odróżnianej od filozofa kojarzonego najczęściej z tradycją zachodnią).

Trawestując tytuł niniejszych rozważań, można by uznać, że zarysowana tu perspektywa ewolucyjna powinna skłaniać raczej do poszukiwania

18 W. P i e 1 e w i n, Maty palec Buddy, tłum. H. Broniatowska, Warszawa 2003, s. 383. Tytuł oryginału: Чanaeb u Пycmoma. 
obecności Pielewina we współczesnym tekście rosyjskim, aniżeli Rosji w tekstach Pielewina. Ogromna popularność pisarza, atrakcyjność jego wizji rzeczywistości i sposobów zjednywania dla niej bardzo różnych grup odbiorców ${ }^{19}$, a nadto jego nieuchwytna, na wpół wirtualna, lecz jednocześnie imponująco skuteczna zdolność do autokreacji, każą sądzić, że mamy tu do czynienia z daleko posuniętą zbieżnością duchowo-intelektualnej formacji i społecznego na nią zapotrzebowania.

\section{Bibliografia}

B a u m a n Z., Ponowoczesność jako źródło cierpień, Warszawa 2000.

M a r q u a r d O., Aesthetica i anaesthetica. Rozważania filozoficzne, tłum. K. Krzemieniowa, Warszawa 2007.

Mentalność rosyjska, red. A. de Lazari, Katowice 1995.

P i e l e w i n W., Empire V. Opowieść o prawdziwym nadczłowieku, tłum. E. Rojewska-Olejarczuk, Warszawa 2008.

P i e l e w i n W., Generation 'P', tłum. E. Rojewska-Olejarczuk, Warszawa 2006.

P i e l e w i n W., Maty palec Buddy, tłum. H. Broniatowska, Warszawa 2003.

P i e le w in W., Omon Ra i inne opowieści, tłum. E. Rojewska-Olejarczuk, Warszawa 2007.

P i e l e w i n W., Życie owadów, tłum. E. Rojewska-Olejarczuk, Warszawa 2004.

Б о г д а н о в а О., Постмодернизм 6 контексте современной русской митературы (60-90-е годы ХХ века - начало ХХІ века), Санкт-Петербург 2004.

Г е н и с А., Феномен Пелевина, [w:] źródło elektroniczne: http://pelevin.nov.ru/stati/ o-gen1/1.html (15.08.2015).

К о р н е в С., Столкновение пустот: может ли постмодернизм быть русским и классическим?, „Новое литературное обозрение” 1997, № 28.

К р о п ы в ь я н с к и й Л., Интервъю с Виктором Пелевиным, [w:] źródło elektroniczne: http://pelevin.nov.ru/interview/o-bomb/1.html (15.08.2015).

К у р и цын В., Русский цитературный постмодернизм, Москва 2000.

С к о р о п а н о в а И., Русская постмодернистская литература, Москва 2001.

Ш а м а н с к и й Д., Пустота (Снова о Викторе Пелевине), „Мир русского слова” 2001, № 3.

\footnotetext{
19 Pielewin - zauważa Aleksander Genis - w ciągu dziesięciu lat pracy pomógł skierować rodzimą literaturę w stronę XXI wieku. Przywrócił książkę odsuniętemu od niej z odrazą czytelnikowi, opanował młodzież internetową, rozzłościł krytyków, wzbudził zainteresowanie sennego Zachodu.
}

А. Г е н и с, Феномен Пелевина, [w:] źródło elektroniczne: http://pelevin.nov.ru/stati /o-gen1/1.html (15.08.2015). 
